\title{
Mobbing: A theoretical model quantifying factors affecting the role of women executives in the institutions of public education in Mexico
}

\section{Mara Maricela Trujillo}

Flores

Escuela Superior de Comercio y Administración Santo Tomás, Instituto Politécnico Nacional matrui@aol.com

Luis Arturo Rivas Tovar Escuela Superior de Comercio y Administración Santo Tomás, Instituto Politécnico Nacional larrivas33@hotmail.com

\section{Fernando Lámbarry}

Vilchis

Escuela Superior de Comercio y Administración Santo Tomás, Instituto Politécnico Nacional flambarry@gmail.com

\section{Abstract}

From a comprehensive review of the state of the art about mobbing, the models used on its quantification were identified. The data analysis concluded that there is a variety within variables used to measure the phenomenon; it stands out that none of them considers the emotional intelligence variable, nor the models' little gender orientation in organizations, particularly in public higher education institutions, despite being a notorious sector with a high rate incidence of the phenomenon. A diagnosis was made at Instituto Politécnico Nacional (IPN) Higher Education Institutions (HEI) which revealed that there are some variables that could be mobbing causes. The research field analysis allows proposing a theoretical model about mobbing among IPN civil servant women. This is a descriptive-explanatory research. This model integrates emotional intelligence and victims' and bullies' personality as determining variables.

Keywords: mobbing work, instrument, gender perspective executive women, mobbing. 


\section{Modelo teórico de cuantificación de mobbing para mujeres ejecutivas en una institución educativa pública de nivel superior en México}

\section{Resumen}

A partir de una revisión sobre el estado del arte en mobbing se identificaron los modelos utilizados en su cuantificación. El análisis de la información concluyó que existe una diversidad en las variables utilizadas en la medición del fenómeno, matizando que ningún modelo considera la variable de inteligencia emocional, ni la poca orientación de los modelos hacia la perspectiva de género en organizaciones y particularmente en instituciones de educación superior pública, a pesar de ser un sector señalado con un índice alto de incidencia del fenómeno. Fue realizado un diagnóstico en el Instituto Politécnico Nacional (IPN) en sus Instituciones de Enseñanza Superior (IES) que reveló que existen variables que podrían ser causas de mobbing. El análisis de la investigación sobre el campo permite proponer un modelo teórico sobre mobbing para mujeres funcionarias del IPN. Esta investigación es descriptiva-explicativa. Este modelo integra la inteligencia emocional y la personalidad de las víctimas y acosadores como variables determinantes.

Palabras clave: mobbing, variables, perspectiva de género, mujeres ejecutivas.

\section{Introduction}

One of the current labor problems due to the highly competitive environment is labor harassment (Baron and Neuman, 1998). The injury is psychological, and results on the phenomenon known as mobbing. Moreno-Jiménez, Rodríguez-Muñoz, Garrosa and Morante (2005) found many explanations such as: poor conflict management, poor organizational practices, weakened organizational environments, among others; this is why it is considered a multicausal phenomenon (Hoel and Salin, 2003; Moreno-Jiménez et al., 2005; Zapf, Knorz and Kulla 1996). Mobbing induces negative consequences (Einarsen and Mikkelsen, 2003; González de Rivera and Rodríguez-Abuín, 2006; Leymann and Gustafsson, 1996; Matthiesen and Einarsen, 2001, 2004, according to Mikkelsen and Einarsen, 2002a, 2002b), mobbing often transcends into the socio-family sphere (Pérez-Bilbao et al., 2001), and it also damages the workplace (Einarsen and Hauge, 2006).

This paper presents researches on mobbing organizational implications which are: work organization and conflict management systems. On work organization, outstanding papers are: Ferrie et al. (1998), which states that significant changes in 
work organization and job insecurity have harmful effects on the workers psychophysical health. MacDonald et al. (2001) researched physical and psychosocial stressors and its impact. Elovainio, Kivimaki and Vahtera (2002) investigated that poorly balanced equity constitutes a risk to the workers welfare.

In order to get an overview, papers about conflict and mobbing were reviewed, such as those from Galtung (1998), Lederach $(1984,1994,1996)$ and Ficher and Ury (1992) along with theorists that study curriculum and organization (Jares, 1996, 2001) with more cultural and socio-critical approaches. These approaches provide clues to understand the coexistence of problems and conflicts. On conflict management systems the outstanding papers are: Dormann and Zapf (2002), concerning climate and culture, and Cole and Grubb (2005), that report that it affects productivity. Skogstad (1996) explains that internal restructurings affect and cause more conflict. These factors have in common their potentially stressing character which is associated to mobbing. There are also mexican authors such as Juárez (2005), Rosas (2008) and Fondevila (2008) who agree that impoverished working conditions favor the occurrence of mobbing behavior at workplace, related to wrong handling of factors that may be social, psychological, organizational, cultural, political, organizational, economic and political-organizational. In Mexico, the phenomenon has been studied almost exclusively by the anthropology area standing out papers like those of Peña, Ravelo and Sánchez (2007), as well as Pando et al. (2009), who have conducted studies in the education area with teachers as research subjects. Another relevant paper is Cortés (2009) on occupational health and law in Yucatan.

Social factors related to mobbing within the organization are associated with how people behave and relate in their work environment using different leadership styles; on this line, there are the researches of Vartia (1996, 2006), O'Moore (2003), Hubert and Veldhoven (2002), Einarsen, Raknes and Matthiesen, (1994), Zapf, Knorz and Kulla, (1996). On psychological factors, Rayner and Cooper (2003), express that somehow the victim and the harasser personalities are the conflict starting points. Referring to organizational factors, there is the DiMartino, Hoel and Cooper paper (2007). On mishandling of cultural factors there is the Cole and Grubb research (2005). As for economic factors there are the Bjökqvist Cols and Vartia reported papers (2002). In reference to political-organizational aspects, Björkqvist (1992) states that some organizations have hidden policies that allow the phenomenon to form. About the aggressors' personality, García-Izquierdo and Sáez (2007), and Davenport et al., (1999) papers stand out, explaining that the 
harasser is characterized by a controlling orientation, jealousy, lust for power and limited social skills. Zapf and Einarsen (2003) point that the phenomenon is related to the aggressor's self-esteem. Also, Ashforth (1994), Baumeister, Heatherton and Tice (1993) indicate that an excessively high self-esteem can lead to tyrannical behavior. But there is also the position that mobbing can be a way to protect an unstable self-esteem and insecurities, according to Leymman (1996). Another position is that of Ashforth (1994), who outlines the idea that a sick, violence inclined personality can trigger the phenomenon.

The inherent characteristics of human relationships as causal explanations of the phenomenon are exemplified in the Hubert and Veldhoven paper (2002). On the other hand, Brodsky (1976) argues that competition is inherent in all social, ethnic and racial groups to the extent that there is a constant process of adjust assessment between oneself and others in order to establish the place each one occupies within hierarchy.

In relation to environment elements and work organization there are the Thylefors (1987) papers which have shown that bullying is more common in large, bureaucratic organizations, where the harasser may go unnoticed. Also, mobbing is more common in organizations with poor internal communication and bad social climates (Einarsen, Raknes and Matthiesen, 1994; Moreno-Jiménez et al., 2004), and where unhealthy behaviors are tolerated (Einarsen, 2000). This suggests that the problem settles its etiological origin in the factors derived from the work organization.

\section{Quantification of the phenomena}

The Helsinki 2006 Reunion announced that work violence in Europe in 2004 was of 4\%; in 2005 the number is repeated, and in 2006, it rises to 5\% and it is unfortunate that in 2007 it reached 6\%. These measurements have led to mobbing quantification with increased rigor, (Ministry of Labour and Social Affairs, 2007). In reference to productive sectors, DiMartino, Hoel and Cooper (2003), in their research indicate the following values for mobbing: public administration and defense, 14\%; education and health, $12 \%$; hotels and restaurants, $11 \%$; transport and communications, $10 \%$; with all these having higher rates than, for example, agriculture and fisheries which reach $3 \%$. However, when reviewing the data on this point, not all studies agree that these sectors are the most affected (Einarsen, Raknes and Matthiesen 1994; Einarsen and Skogstad 1996). 
Talking about gender, Benhabib and Cornell (2002) indicate that the gender approach is based on the theory by the same name and is part of three paradigms: the historical-critical theory, culture of feminism and human development. Thus the gender perspective emerges as an analysis category of social and political reality in the late twentieth and early twenty-first century, having its roots in historical materialism, which is an anthropology view that considers feminine and masculine are dimensions of cultural origin within humans, disregarding any relevance of biological data. Scott (2003), on the other hand, provides a scientific, analytical and policy vision on women and men, which intends to eliminate the causes of gender oppression as inequality, injustice and hierarchy of people based on gender and promoting equality through equity, women welfare and contributes to building a society where women and men have the same value, equal rights and opportunities for access to economic resources and political and social representation in the decision making field (De Barbieri 2005). This study takes gender as an analysis unit.

According to available statistics, bullying is increasing within industrialized societies, affecting the individual's rights; this is why it is important to analyze it under this point of view (Kahlor and Amin 2006). From the administrative perspective, the phenomenon has been investigated by specific studies (using only one variable) or by models (two or more variables). The most cited ones in each mode are as follows.

\section{Specific studies}

Under these, we considered the following authors: Lindroth and Leymann (1998), who used the measures of safety and hygiene variable. Lindroth and Leymann, (1998), researched inadequate provisions to protect employees concerning clerical diseases. The hazardous work environment variable is a recurring theme in Hirigoyen papers (2002) and also the change in the organization tends to create risky job scenarios according to Hirigoyen (2002). The work of Matthiesen and Eirnarsen (2001) is about the technology changes that severely affect individuals. Under strong internal restructurings there may result mobbing, explains Skogstad (1996). The abatement costs to occupy special niches in world markets can cause the appearance of the phenomenon (Bjökqvist and Vartia, 2002; Gil, 2002). On climate and organizational culture, it was found that the highest incidence of violence in general and in particular mobbing is located in workplaces with poor organizational climate (Cole and Grubb, 2005). In relation to authoritarian management styles or laissez-faire and mobbing, there are the O'Moore (2003), Vartia (2006), 
Hubert and Veldhoven (2002) papers. Many studies on stress have concluded that harassment is associated with negative and stressful environments (Agervold, 2002). Role ambiguity, lack of planning or poor distribution of work tasks, misinformation about the tasks to be performed by employees, or about the obligations they have to do, give rise to conflicts that may trigger the phenomenon (Quine, 1996). The temporary nature of the phenomenon has been used by different authors as Hoel, Zapf and Cooper (2003), Zapf and Gross (2001), Einarsen (2000) and Björkqvist (1992). A variety of behaviors are focused on the presence of various individual pathological personalities which may affect the workplace; case studies are those by Einarsen (2000) and Björkqvist (1992).

In respect to emotional states the current discourse establishes that the relationship that exists between job demands and the person characteristics is not of automatic nature, nor a comparison of objective nature, but it is mediated by the particular perception that the individual has of it, and therefore it is influenced by subjective aspects (Matud et al., 2006). Daza (2007) believes that in the generation of stress the significance and even the existence of a possible mismatch situation come from the appreciation the subject has of that situation. The same author adds that psychological harassment at work is an interpersonal conflict and may face one or several individuals: the one with the harasser behavior, and those who suffer from it. Therefore, in studies on mobbing, we have to take into account personality factors both from the harasser and the victim (Daza 2008). Likewise, there is a fundamental relationship between cognitive perception of the individual and the stressful environment at the time of generating a stress process. Thus, personality is an important part in the genesis of the phenomenon and it is suggested that it is better to analyze the dynamics that occurs in stress from the relationship and the comparison constituted between job demands and characteristics of the person, taking into account their emotional states. Rodríguez (2007), in his book Emotional intelligence in working stress explains the origin, persistence and prevalence of mobbing in work organizations. Thus, in the mobbing and emotional intelligence (EI) variable it can be said that mobbing limits the functioning of EI. On this regard, Leymann $(1993,1996)$ said that the harasser's personality is not a factor to make him prone to suffer from mobbing, but on the other side, there stand Matthiensen and Einarsen (2001), and Medina et al. (2002), who found from their studies that there is great diversity in how people react to interemotional conflicts and the escalation of conflict at work. The authors of this study reflect the comments of most recent researchers and believe that emotional intelligence (EI) is a variable immersed in the causes that can cause mobbing. 
Operationalization of variables has been diverse since the authors have used different scenarios, therefore, the characteristics of the study subjects have led to a diversity of variables used, some of the examples are: Leymann $(1984,1987$, $1990,1996,1997)$ focuses its research on different sectors of the swedish population, using the following variables: limited communication, limited social contact, to get discredit before one's peers, disparage and discredit their professional capacity and labor, compromising health. Adams and Crawford (1992) focus their researches on the service sector and use a sample of self-help groups, where the variables are: presence of violence, intensity of violence and bullying. Hirigoyen (2005) employs female patients from different social classes using variables of domestic violence. Piñuel y Zavala, from 2001 to 2010, studied various sectors such as health, education and economy; their most frequent variables were: organizational factors and factors specific to the organization, cognitive variables and leadership. Morán-Astorga (2002), have directed their work to the legal aspect of the phenomenon, using variables of frequency, incidence, and legal components. Baron-Duke (2003) for his part has dabbled in various service organizations, using variables such as leadership, communication, organizational factors. González de Rivera (2005) used by the industry and the health and where the variables are: physical health, psychological health, emotional health. Björkqvist, Osterman and Lagerspetz (2005) used the members of the Finnish Federation of Municipal Authorities, and prison officials using variables such as workplace harassment, workplace environment and climate in the work unit. Einarsen and Hoel (2001) have entered various employment sectors in Great Britain, using variables such as conflict, interpersonal relationships, personality factors, values.

\section{Mobbing models}

The models analyzed in this study were: Langner (1962) who originally developed a model as part of a Midtown Manhattan study as a means of assessment of psychiatric disorders, he is the first to hold variables that talked about the workplace variables used incipiently as actions to discredit the workers, self-esteem and organizational characteristics. Goldberg (1972) in the General Health Questionnaire (GHQ), which is not really a tool for quantification of mobbing, but a tool which includes actions that may harm the worker in his work. López, Hoel and Zapf (1994) apply a questionnaire to the administrative sector. Leymann (1996) with a first study performed at the Swedish National Board of Occupational Safety and Health in Stockholm, in a later form he quantifies the phenomenon in various occupational sectors in Europe. Zapf, 
Knorz and Kulla (1996) developed their work in different work scenarios in the medical field in America USA and Sweden. Langner (1996), an instrument designed to assess health particularly in the metallurgical sector. Einarsen, Raknes and Matthiesen (1997), with this scale it has been possible to evaluate different scenarios in Great Britain, Scandinavian and German countries. Quine (2000), his research was conducted in British scenarios such as construction, tourism service. Piñuel y Zavala (2001) evaluated bullying in the education sector with different subjects. Knorz and Zapt (2003) have addressed their research to the health sector. Björkqvist, Osterman and Lagerspetz (2004) the field work of these authors has been in the education sector. Van Dick and Wagner (2004), as well as previous authors, have also addressed the educational scenario. The models shown have allowed quantifying the phenomenon in different settings and different subjects. One important thing observed is that most gender research uses only sociodemographic variables instead of proposed studies, Björkqvist, Osterman and Lagerspetz, in the educational context, discuss mobbing from the edge of gender.

The analyzed conceptual framework shows multiple specific studies and quantification models, although it is not possible to draw from this fact unified conclusions about the variables that surround the phenomenon and the instruments to be used, since they used different criteria and different contexts in their structure as well as different study subjects, unequal operationalizations, and they use multiple indicators. This means that a comparison of their results is impossible. It should be mentioned that only 5\% of the studies handled the gender variable. Another interesting point is the fact that $38 \%$ of investigations are oriented to the education sector, but none to women executives.

It has to be remarked that mexican government has two main objectives: economic policy and social policy. The second one has a series of actions, one of these being the opportunities policy. Also, the Plan Nacional de Desarrollo (PND) 2007-2012, states that the purpose of social policy is to achieve human development and mexicans' welfare through equality of opportunities. In order to lead Mexico to a sustainable social and economic development the serious differences that prevail in the country have to be profoundly solved (PND, 2007-2012). Labour policy is seen as an issue linked to the quality of life for mexicans, because employment is the key source of individuals and families income. Questioning about the perspective of inequality and discrimination in the PND, particularly on women, the answer says that it is doubly unfair, since women still face inequality, discrimination, violence and abuse. It is necessary that society and government assume the obligation 
of ending this situation and achieving an effective equality between genders. This led to use a gender perspective on this research (PND, 2007-2012).

The data indicate that a risk sector is that of education (12\%) (Piñuel y Zavala, 2007; Einarsen and Hauge, 2006; Vartia 2006). Thylefors (1987) and Einarsen (2000) found that the phenomenon is more prevalent within large, bureaucratic organizations, this being the case of public institutions.

\section{Method}

This is a review article. For its development, different databanks and specific databases were surveyed. Methodologically, the research is formed by several phases: Phase 1, a literature search on specific sources was conducted to identify, select, retrieve and analyze mobbing papers about authors and quantification. Phase 2, quantification studies and models were chosen related to work environment, performing an analysis of the used variables. Phase 3, the characteristics of the institution of higher education that was used as a context were established, in relation to this, the views of key officials were sought, who said, in reference to the selected variables: first, whether they were in context; second, whether they were representative of the women officers. Phase 4, in which variables were selected and their conceptualization was established, thus reaching a proposed ex ante model which will allow evaluating the phenomenon.

\section{Phase's development}

Phase 1 allowed the construction of the conceptual framework and the data analysis. Phase 2, on this part, table 1 was built, which shows specific studies classified by variable used, by authors and the study characteristics as well as the study area. 


\section{Table 1}

\section{Mobbing specific studies for the organization}

\begin{tabular}{|c|c|c|}
\hline Authors & Variables & Specific study characteristics \\
\hline \multicolumn{3}{|c|}{ Organizational factors analysis } \\
\hline $\begin{array}{l}\text { DiMartino, Hoel and Cooper } \\
\text { (2007) }\end{array}$ & Organizational factors & $\begin{array}{l}\text { Organizational structure. } \\
\text { Communication within the organization. }\end{array}$ \\
\hline Hirigoyen (2004) & Phycological profiles & $\begin{array}{l}\text { Description of the profiles of the harraser } \\
\text { and victim. There is a paucity of hard data } \\
\text { in this field of study. }\end{array}$ \\
\hline \multicolumn{3}{|c|}{ Hygiene and security measures } \\
\hline Lindroth and Leymann (2001) & $\begin{array}{l}\text { Hygiene and security } \\
\text { measures }\end{array}$ & $\begin{array}{l}\text { This study exposes the need for adequate } \\
\text { hygiene and security measures: the absence } \\
\text { of both contributing to physical and social } \\
\text { disease among employees. Focus is on } \\
\text { Mobbing in the Construction Work sector. }\end{array}$ \\
\hline \multicolumn{3}{|c|}{ Risky work environments } \\
\hline Hirigoyen (2002) & Different work environments & $\begin{array}{l}\text { Analysis of the work environments that } \\
\text { contribute to the phenomena of mobbing. } \\
\text { Focus on Private Sector Administration. }\end{array}$ \\
\hline \multicolumn{3}{|c|}{ Technological change } \\
\hline Matthiesen and Cols (2001) & $\begin{array}{l}\text { Competition and technological } \\
\text { change }\end{array}$ & $\begin{array}{l}\text { Analysis of how technological change and } \\
\text { strategies employed by companies in the } \\
\text { search for competitiveness cause problems } \\
\text { which lead to mobbing. Focus on the area of } \\
\text { Communications. }\end{array}$ \\
\hline \multicolumn{3}{|c|}{ Restructuring } \\
\hline Skogstad (1996) & $\begin{array}{l}\text { Power changes } \\
\text { Uncertainty }\end{array}$ & $\begin{array}{l}\text { States how vigorous internal restructuring } \\
\text { within a company generates anxiety among } \\
\text { employees. Focus is on rising conflict due } \\
\text { to an increase of stress. Tourism sector. }\end{array}$ \\
\hline \multicolumn{3}{|c|}{ Costs abatement } \\
\hline $\begin{array}{l}\text { Bjökqvist, Cols and Vartia } \\
\text { (2002) }\end{array}$ & Costs & $\begin{array}{l}\text { An analysis of the effects of Cost cutting } \\
\text { measures designed to help a company } \\
\text { occupy a special niche in global markets } \\
\text { and how employees are submitted to greater } \\
\text { competitiveness and the results of such } \\
\text { factors. Tourism sector. }\end{array}$ \\
\hline Alburqueque (2006) & Productivity and costs & $\begin{array}{l}\text { The study is focused on determining the } \\
\text { economic cost of meeting productivity } \\
\text { targets. Transportation sector. }\end{array}$ \\
\hline \multicolumn{3}{|c|}{ Culture and climate } \\
\hline Cole and Grubb (2005) & $\begin{array}{l}\text { Work climate } \\
\text { Work groups }\end{array}$ & $\begin{array}{l}\text { How poor organization leads to conflict } \\
\text { and violence in the work place as well as a } \\
\text { diminished team effort. Defense sector. }\end{array}$ \\
\hline
\end{tabular}




\begin{tabular}{|c|c|c|}
\hline Authors & Variables & Specific study characteristics \\
\hline \multicolumn{3}{|c|}{ Management styles } \\
\hline Vartia (2006) & $\begin{array}{l}\text { Absence of leadership } \\
\text { Authority leadership }\end{array}$ & $\begin{array}{l}\text { How the presence of a strong democratic } \\
\text { leadership promotes balance and } \\
\text { equilibrium at the work site. Whereas, an } \\
\text { Authoritarian style leadership gives way } \\
\text { to Mobbing and other difficulties. Public } \\
\text { Administration sector. }\end{array}$ \\
\hline O’Moore (2003) & $\begin{array}{l}\text { Management styles } \\
\text { Authoritarian } \\
\text { Weak (laissez-faire) } \\
\text { Mobbing }\end{array}$ & $\begin{array}{l}\text { The study presents the correlation between } \\
\text { the authoritarian management style and the } \\
\text { laissez-faire option and the effects on } \\
\text { mobbing. Health sector. }\end{array}$ \\
\hline Hubert and Veldhoven (2002) & $\begin{array}{l}\text { Laissez-faire } \\
\text { Mobbing }\end{array}$ & $\begin{array}{l}\text { How ignorance and impunity grant their } \\
\text { seal of approval for mobbing within the } \\
\text { organization. Education sector. }\end{array}$ \\
\hline \multicolumn{3}{|c|}{ Stress } \\
\hline Agervold (2002) & $\begin{array}{l}\text { Stressing negative } \\
\text { environments } \\
\text { Mobbing }\end{array}$ & $\begin{array}{l}\text { This study conclusion associates harassment } \\
\text { to negative and stressing environments. } \\
\text { Health area. }\end{array}$ \\
\hline \multicolumn{3}{|c|}{ Job Profiles andAmbiguity } \\
\hline Quine (1996) & $\begin{array}{l}\text { Conflict of values } \\
\text { Lack of planning } \\
\text { Poor tasks distribution }\end{array}$ & $\begin{array}{l}\text { Inadequate tasks assignments due to poor } \\
\text { planning. The achievement of goals and the } \\
\text { problem of conflicting values in the work } \\
\text { place. Diverse Work-place sectors. }\end{array}$ \\
\hline \multicolumn{3}{|c|}{ Seasonal Factors } \\
\hline Hoel, Zapf and Cooper (2003) & Phenomenon frecuency & $\begin{array}{l}\text { The phenomenon of Seasons leads to } \\
\text { a gradual process in time and style. } \\
\text { Communication and Transportation sector. }\end{array}$ \\
\hline \multicolumn{3}{|c|}{ Diverse Behavior } \\
\hline Einarsen (2000) & Behavior diversity & $\begin{array}{l}\text { Beyond an occasional event this is a } \\
\text { process involving long term and repetitive } \\
\text { behaviors. Educational Sector }\end{array}$ \\
\hline Björkqvist (1992) & $\begin{array}{l}\text { Different negative and } \\
\text { positive conducts } \\
\text { Mobbing }\end{array}$ & $\begin{array}{l}\text { Study focused on hostile behaviors } \\
\text { manifested in a subtle and often unnoticed } \\
\text { demeanor within the work group and } \\
\text { organization. Health sector. }\end{array}$ \\
\hline
\end{tabular}

Source: Own elaboration with material from the cited authors.

Another point made within phase 2 was to verify whether the variables of these studies appear in the mobbing quantification models. The information was crossed in order to observe the specific studies incidence with models variables that have statistical support and whose authors are on the frontier of knowledge of the subject matter. See table 2 . 


\section{Table 2}

\section{Model variables and specific study variables}

\begin{tabular}{|c|c|c|}
\hline Authors & Model variables & Specific studies variables \\
\hline $\begin{array}{l}\text { Langner model } \\
\text { (1962) }\end{array}$ & $\begin{array}{l}\text { - Actions to discredit the workers } \\
\text { - Self-esteem } \\
\text { - Organization characteristics }\end{array}$ & $\begin{array}{l}\text {-Analysis of organizational fac- } \\
\text { tors present in the study: DiMar- } \\
\text { tino, Hoel and Cooper (2007). } \\
\text {-Psychological profiles present } \\
\text { in the study: Hirigoyen, (2004). }\end{array}$ \\
\hline $\begin{array}{l}\text { Goldberg model } \\
\qquad(1972)\end{array}$ & $\begin{array}{l}\text { In a general health instrument and uses as variables: } \\
\text { - Insecurity at work } \\
\text { - Stressors } \\
\text { The two variables mentioned are routed to harassment } \\
\text { actions }\end{array}$ & $\begin{array}{l}\text {-Hazardous work environments } \\
\text { present in the study: Hirigoyen, } \\
(2002) \\
\text {-Stress in the present study: } \\
\text { Agervold, (2002). }\end{array}$ \\
\hline $\begin{array}{l}\text { López, Hoel, and } \\
\text { Zapf model (1994) }\end{array}$ & $\begin{array}{l}\text { López and his working group used as variables: } \\
\text { - Personality traits } \\
\text { - Internal features of the organization }\end{array}$ & $\begin{array}{l}\text {-Analysis of organizational factors } \\
\text { present in the study: DiMartino, } \\
\text { Hoel and Cooper (2007). } \\
\text {-Psychological profiles present } \\
\text { in the study: Hirigoyen, (2004). }\end{array}$ \\
\hline $\begin{array}{l}\text { Leymann model } \\
\text { (1996) }\end{array}$ & $\begin{array}{l}\text { - Harassment activities to reduce chances of the victim to } \\
\text { communicate well with others, including his own harasser } \\
\text { - Harassment activities to prevent the victim from } \\
\text { maintaining social contacts } \\
\text { - Harassment activities aimed at discrediting the vic- } \\
\text { tim and keeping him/her from a personal or business } \\
\text { reputation } \\
\text { - Harassment activities aimed at reducing the victim's } \\
\text { occupation and employability through professional } \\
\text { discredit } \\
\text { - Harassment activities affecting the victim's physical } \\
\text { or mental health }\end{array}$ & $\begin{array}{l}\text {-Analysis of organizational } \\
\text { factors present in the study: } \\
\text { DiMartino, Hoel and Cooper } \\
(2007) \text {. }\end{array}$ \\
\hline $\begin{array}{c}\text { Zapf, Knorz and } \\
\text { Kulla model (1996) }\end{array}$ & $\begin{array}{l}\text { The research group used in their research the following } \\
\text { variables: } \\
\text { - Attacks on the victim with organizational measures } \\
\text { - Attacks on the victim's social relations with social } \\
\text { isolation } \\
\text { - Attacks on the victim's private life } \\
\text { - Physical violence } \\
\text { - Attacks on the victim's attitudes } \\
\text { - Verbal aggression } \\
\text { - Rumors }\end{array}$ & $\begin{array}{l}\text {-Analysis of organizational } \\
\text { factors present in the study: } \\
\text { DiMartino, Hoel and Cooper } \\
\text { (2007). } \\
\text {-Stress present in Agervold } \\
\text { studies (2002). }\end{array}$ \\
\hline $\begin{array}{l}\text { Langner model } \\
\text { (1996) }\end{array}$ & $\begin{array}{l}\text { The variable of this author refers to the metallurgical } \\
\text { sector specifically: } \\
\text { - Actions to discredit workers } \\
\text { - Self-esteem } \\
\text { - Organization characteristics }\end{array}$ & $\begin{array}{l}\text {-Analysis of organizational fac- } \\
\text { tors present in the study: DiMar- } \\
\text { tino, Hoel and Cooper (2007). } \\
\text {-Psychological profiles present } \\
\text { in the study: Hirigoyen (2004). } \\
\text {-Ambiguity of roles present in } \\
\text { the study: Quine (1996). }\end{array}$ \\
\hline
\end{tabular}




\begin{tabular}{|c|c|c|}
\hline Authors & Model variables & Specific studies variables \\
\hline $\begin{array}{l}\text { Einarsen, Raknes } \\
\text { and Matthiesen } \\
\text { model (1997) }\end{array}$ & $\begin{array}{l}\text { Use a range of different behaviors as variables, all } \\
\text { focused on leadership styles }\end{array}$ & $\begin{array}{l}\text {-Management styles present } \\
\text { in the study: Vartia (2006), } \\
\text { O'Moore (2003), Hubert and } \\
\text { Veldhoven (2002). }\end{array}$ \\
\hline Quine model (2000) & $\begin{array}{l}\text { This author uses several variables such as: } \\
\text { - Situational factors } \\
\text { - Hierarchical factors } \\
\text { - Identity Factors }\end{array}$ & $\begin{array}{l}\text {-Analysis of organizational } \\
\text { factors present in the study: } \\
\text { DiMartino, Hoel and Cooper } \\
\text { (2007). } \\
\text {-Ambiguity of roles present } \\
\text { in studies of Zapf and Gross } \\
(2001) \text {. }\end{array}$ \\
\hline $\begin{array}{l}\text { Piñuel y Zavala } \\
\text { model (2001) }\end{array}$ & $\begin{array}{l}\text { Choice of variables taking into account the } \\
\text { organization. The model proposes: } \\
\text { - Situational factors } \\
\text { - Forms of work organization } \\
\text { - Harasser's personal factors } \\
\text { - Organizational behavior }\end{array}$ & $\begin{array}{l}\text {-Analysis of organizational } \\
\text { factors present in the study: } \\
\text { DiMartino, Hoel and Cooper } \\
\text { (2007). } \\
\text {-Management styles present } \\
\text { in the study: Vartia (2006), } \\
\text { O'Moore (2003), Hubert and } \\
\text { Veldhoven (2002). } \\
\text {-Psychological profiles present } \\
\text { in the study: Hirigoyen (2004). }\end{array}$ \\
\hline $\begin{array}{l}\text { Einarsen and Hoel } \\
\text { model (2001) }\end{array}$ & $\begin{array}{l}\text { Use variables centered in the harasser: } \\
\text { - Psychological Profiles } \\
\text { - Frequency }\end{array}$ & $\begin{array}{l}\text {-Psychological profiles present } \\
\text { in the study: Hirigoyen (2004). } \\
\text {-Temporarily present in the } \\
\text { following studies: Hoel, Zapf } \\
\text { and Cooper (2003). }\end{array}$ \\
\hline $\begin{array}{l}\text { Knorz and Zapt } \\
\text { model (2003) }\end{array}$ & $\begin{array}{l}\text { Leymann variables used and it is focused on the lack } \\
\text { of: } \\
\text { - Social skills } \\
\text { - Temporality }\end{array}$ & $\begin{array}{l}\text {-Analysis of organizational } \\
\text { factors present in the study: } \\
\text { DiMartino, Hoel and Cooper } \\
\text { (2007). } \\
\text {-Temporarily present in the } \\
\text { following studies: Hoel, Zapf } \\
\text { and Cooper (2003). }\end{array}$ \\
\hline $\begin{array}{l}\text { Björkqvist, } \\
\text { Österman and } \\
\text { Lagerspetz model } \\
\text { (2004) }\end{array}$ & $\begin{array}{l}\text { Used as a fundamental variable of the the sudy the } \\
\text { gender approach }\end{array}$ & $\begin{array}{l}\text {-An original study, which being } \\
\text { directed to gender makes it } \\
\text { unique. }\end{array}$ \\
\hline $\begin{array}{l}\text { Van Dick and } \\
\text { Wagner model } \\
\quad(2004)\end{array}$ & $\begin{array}{l}\text { Another adaptation from Leymann's instrument, } \\
\text { where only fit items: } \\
\text { - The boss treats me like I was invisible } \\
\text { - The boss often criticizes me for no reason } \\
\text { - My peers spread rumors about me } \\
\text { - I tend to be excluded from social activities }\end{array}$ & $\begin{array}{l}\text {-Management styles present } \\
\text { in the study: Vartia (2006), } \\
\text { O'Moore (2003), Hubert and } \\
\text { Veldhoven (2002). }\end{array}$ \\
\hline
\end{tabular}




\begin{tabular}{|c|c|c|}
\hline Authors & Model variables & Specific studies variables \\
\hline $\begin{array}{l}\text { Adapted by García- } \\
\text { Izquierdo, Sáez } \\
\text { Ruiz Blasco and } \\
\text { Campillo (2004), } \\
\text { from the Einarsen } \\
\text { and Hoel model } \\
\text { (2001) }\end{array}$ & $\begin{array}{l}\text { Core variables used in the model tropicalization: } \\
\text { - Temporality } \\
\text { - Phenomenon frequency }\end{array}$ & $\begin{array}{l}\text {-Temporarily present in the } \\
\text { following studies: Hoel, Zapf } \\
\text { and Cooper (2003). }\end{array}$ \\
\hline $\begin{array}{l}\text { González de Rivera } \\
\text { model (2005) }\end{array}$ & $\begin{array}{l}\text { Uses the Leymann tool and only adds model items } \\
\text { with a specific orientation: } \\
\text { - Damage to their belongings or work equipment } \\
\text { necessary and important for its role } \\
\text { - Confidential and negative reports about the person } \\
\text { - Minimize the person hiding their special skills and } \\
\text { abilities }\end{array}$ & $\begin{array}{l}\text {-Analysis of organizational fac- } \\
\text { tors present in the study: DiMar- } \\
\text { tino, Hoel and Cooper (2007). } \\
\text { - Temporarily present in the } \\
\text { following studies: Hoel, Zapf } \\
\text { and Cooper (2003). } \\
\text {-Psychological profiles present } \\
\text { in the study: Hirigoyen (2004). }\end{array}$ \\
\hline
\end{tabular}

Source: Own elaboration with material from the cited authors.

The frequency (f), presented between the models variables and specific studies was as follows: focused on mobbing actions variables, $\mathrm{f}(9)$; routed on organizational activities that could cause the phenomenon variables, $\mathrm{f}(6)$; hazardous environments that impact the phenomenon variables, $\mathrm{f}(2)$; personality-related variables, $f(1)$; related to organizational factors variables, $f(3)$. An analysis of the universe of study in relation to the problems was added to the above information, in order to obtain a more appropriate handling.

Phase 3. Instituto Politécnico Nacional (IPN) has the following features. It is the second education institution in the country, its structure is complex, classified as a vertical, bureaucratic institution, it consists of 26 senior high schools, 24 of higher education and 17 research centers. It offers training within different knowledge areas: mathematics, natural sciences, social sciences and interdisciplinary sciences. IPN was in its beginnings a response to a need out of the revolution, directing their work towards the formation of mostly male technicians, hence the origin of their chauvinistic policies. The IPN model of formation was a positivist one and it maintains much of this approach today. The culture by merit that recognizes the institute responds to its age and grades obtained. After 75 years of existence, the institution is directed by a woman. This research is directed towards Higher Education Institutions and the study subjects were female officers. As the education sector is of potential risk as mentioned by Piñuel y Zavala (2007), Einarsen and Hauge (2006), Vartia (2006), Instituto Politécnico Nacional was chosen as the universe of the study, and out of it, its 24 Higher Education Institutions (HEI) with 245 
officers of the population (representing one third of institute's total), who became the study subjects. Some practices still in use nowadays are that women in high school experience serious issues to be recognized as legitimate peers and officers, besides being excluded from various working groups because they are women, and usually refer to aspects of their achievements sex, among others.

\section{Results}

The analysis of the information and the diagnosis made indicated first, that there is great diversity in the variables used in the phenomenon quantification. Other gaps indicate a lack of integration of the EI variable and its correlation with mobbing, as well as the minimum use of the gender perspective within organizations and particularly in a public higher education institution, being this a notorious sector with a high rate of incidence of the phenomenon. Also, that within IPN there are variables that could be triggering causes of the phenomenon. Which brings us to establish the lack of a mobbing quantifying model with the mentioned characteristics described in the Latin America case and particularly in Mexico. Thus, the research objective was to select the variables to propose an ex ante theoretical model to mobbing quantification within organizations, and particularly in a Public Higher Education Institution, directed to women officers. This warrants the relevance of a research to which next section shows the methodological approach.

\section{Variables selection}

A diagnosis was made between key officials, in order to get their opinion of the selected variables for the study, and to know if they responded to the characteristics of study subjects (female officers). For purposes of this study a key official was the one who occupied a senior management administrative and may be the school's director or deputy managing director, or the sub managing director, who had at least one year of seniority in office, so as to ensure awareness of the activities carried out by the study subjects selected for this research. The number of participants was 24 officers. In this case, $100 \%$ of their participation was achieved. It's important to note that of the 24 respondents, 11 (45\%) were women and 6 of them $(54 \%)$ exteriorized having observed or having experienced the phenomenon at some point. The exercise was conducted in three stages: in the first one information was provided on the phenomenon and its consequences to executives, in the second stage, using the structured interview, it was asked about the relevance of the obtained variables from the conceptual framework. See table 3. 
Table 3

Relevance of variables

\begin{tabular}{|c|c|c|}
\hline Variables & Comments & Questions used in the structured interview \\
\hline $\begin{array}{r}\text { Sitı } \\
\text { va }\end{array}$ & $\begin{array}{l}\text { When using the variables presented by } \\
\text { Leymann (1996), } 44 \% \text { thought it was } \\
\text { possible that the variable was present, } \\
38 \% \text { said that given the phenomenon the } \\
\text { situations reflected by the variable would } \\
\text { be the correct ones, } 18 \% \text { indicated they } \\
\text { were unaware of the phenomenon and its } \\
\text { consequences. }\end{array}$ & $\begin{array}{l}\text { What is your opinion on IPN organizational } \\
\text { structure? Is the organizational structure } \\
\text { consistent through the IPN HEI? } \\
\text { How do you feel about the communication } \\
\text { channels of chiefs to their staff in IPN HEI? } \\
\text { Does the Institute organization allow social } \\
\text { contact among its employees? } \\
\text { What are the social conditions of work in the } \\
\text { IPN HEI? } \\
\text { Are there policies in IPN in order to safeguard } \\
\text { the personal reputation? } \\
\text { In your opinion, are working conditions } \\
\text { optimal in the HEI of IPN? } \\
\text { How would you describe the IPN HEI } \\
\text { workplace? } \\
\text { Is it common to hear the discrediting of staff } \\
\text { within the IPN HEI? } \\
\text { Does the regulation of IPN allow HEI emplo- } \\
\text { yees maintain their employment status in shape? } \\
\text { Have you received complaints about poor } \\
\text { communication, discrediting, physical or psy- } \\
\text { chological mistreatment in HEI, lack of equip- } \\
\text { ment to develop work by the staff in HEI? } \\
\text { Are there rules under the Regulations in order } \\
\text { to maintain physical health of workers? } \\
\text { Where do most robust complaints come from: } \\
\text { the administrative, faculty or staff? }\end{array}$ \\
\hline $\begin{array}{l}\text { Variables } \\
\text { of cultural } \\
\text { identity } \\
\text { and work } \\
\text { organization }\end{array}$ & $\begin{array}{l}\text { The comment received in relation to } \\
\text { plurality in the culture and customs, also } \\
\text { mentioning the uneven emotional climate } \\
\text { and organizational climate types present } \\
\text { in the HEI of the institute. Another point } \\
\text { was a lack of gender equality by the macho } \\
\text { culture that has prevailed in the institution } \\
\text { and mismanagement of the conflict. It also } \\
\text { marked aspects such as: horizontal and } \\
\text { vertical poor communication. } 64 \% \text { felt that } \\
\text { IPN cultural identity has its source in its own } \\
\text { origins. } 36 \% \text { said that work organization } \\
\text { does not take into account communication } \\
\text { aspects , personal satisfaction and work } \\
\text { recognition for compliance with it, which } \\
\text { could bring negative consequences to the } \\
\text { institute. }\end{array}$ & $\begin{array}{l}\text { How would you describe IPN organizational } \\
\text { culture? } \\
\text { Is the organizational culture for HEI female } \\
\text { officers homogeneous? } \\
\text { Is discrimination tolerated among IPN HEI staff? } \\
\text { What are the meritorious parameters } \\
\text { recognized by IPN staff? } \\
\text { Is the female civil servants (beliefs, ethnicity, } \\
\text { sexual preference etc.) own culture respected } \\
\text { in HEI? } \\
\text { Is work organization homogeneous for IPN } \\
\text { HEI female officers? } \\
\text { Is female officials staff satisfaction appropriate? } \\
\text { Is communication adequate between the senior } \\
\text { command and IPN female staff members? o } \\
\text { Are there permanent programs that assess } \\
\text { performance evaluation, participation, training } \\
\text { among IPN HEI female officers? }\end{array}$ \\
\hline
\end{tabular}




\begin{tabular}{|c|c|c|}
\hline Variables & Comments & Questions used in the structured interview \\
\hline & $\begin{array}{l}\text { The conflict is structured according to } \\
\text { three variables: two of them focused on } \\
\text { the structure, and communication of the } \\
\text { IPN and the third one focused on personal } \\
\text { factors. In relation to to the first one it was } \\
\text { said that the institute presents little flexibility } \\
\text { in regulatory compliance, inadequate } \\
\text { organizational structure, complex internal } \\
\text { regulations causing conflict, it was also } \\
\text { stated that non homogeneous organizational } \\
\text { behaviors as well as the existence of diverse } \\
\text { organizational climates in different HEI } \\
\text { favor the phenomenon occurrence, and } \\
\text { uneven leadership styles caused by different } \\
\text { power groups. Another view was that the } \\
\text { Institute has little recognition forpersonal } \\
\text { achievement. It was also mentioned that } \\
\text { the variety of leadership styles that the } \\
\text { higher management presents, resulting in } \\
\text { different approaches in the HIE direction. } \\
22 \% \text { of respondents felt that these variables } \\
\text { are present in the IPN, } 28 \% \text { believe that the } \\
\text { IPN has the necessary guidelines to prevent } \\
\text { these variables from causing conflicts, } 30 \% \\
\text { said that the communication channels are } \\
\text { different in the HEI and } 20 \% \text { indicated that } \\
\text { it is necessary to adapt the regulations to } \\
\text { each HEI. }\end{array}$ & $\begin{array}{l}\text { Is there a conflict in HEI between their officials? } \\
\text { What are the most common causes of conflict } \\
\text { between this staff section? } \\
\text { What model of conflict resolution is the IPN } \\
\text { using in HEI? } \\
\text { What is the model followed by the institute in } \\
\text { conflict resolution? } \\
\text { In the regulations of the institute is there } \\
\text { reference to a coexistence management model? } \\
\text { In conflict resolution within HEI, what phases } \\
\text { are normatively followed? } \\
\text { What is the approach culture used in resolving } \\
\text { conflicts within the IPN? } \\
\text { Is there stiffness in the communication } \\
\text { standards of the HEI in the IPN? } \\
\text { Does the internal organizational structure of } \\
\text { the HEI results in bureaucracy? } \\
\text { Do you have a leadership model to follow in } \\
\text { the IPN? } \\
\text { Are the leaderships homogenously exercised } \\
\text { in HEI? } \\
\text { Do the HEI resources establish competencies } \\
\text { among staff which can be translated into } \\
\text { dysfunctional conflict? } \\
\text { Are there cases of work overload in HEI? } \\
\text { Is the compensation system of HEI linked to } \\
\text { group performance? } \\
\text { Have there been complaints about development } \\
\text { of unethical practices , authoritarianism, job } \\
\text { insecurity within HEI? } \\
\text { What employment sector has been hardest hit } \\
\text { by reference to the previous question? }\end{array}$ \\
\hline
\end{tabular}




\begin{tabular}{|c|c|c|}
\hline Variables & Comments & Questions used in the structured interview \\
\hline $\begin{array}{c}\text { Emotional } \\
\text { intelligence } \\
\text { variables }\end{array}$ & $\begin{array}{l}\text { On the EI and its association with mobbing. } \\
\text { The } 72 \% \text { said to be unaware if the variable } \\
\text { was affiliated, the } 28 \% \text { said that it would be } \\
\text { suggestive to use it administratively, but it } \\
\text { would be nice to know the association with } \\
\text { the phenomenon. }\end{array}$ & $\begin{array}{l}\text { Do you know the EI therm? } \\
\text { Between interemotional and intraemotional } \\
\text { intelligence, which could lead to more conflict } \\
\text { among staff? } \\
\text { Are interpersonal relationships important in } \\
\text { the activities development of the IPN officials } \\
\text { of the HEI? } \\
\text { Do intrapersonal relationships are important in } \\
\text { the activities development of the IPN officials } \\
\text { of the HEI? } \\
\text { Is EI used as a tool in the HEI to increase } \\
\text { administrative productivity? } \\
\text { For you is there a relationship between EI and } \\
\text { Mobbing? } \\
\text { Is emotion recognition a conflict factor? } \\
\text { Are relationships creating conflicts daily } \\
\text { within the IPN? } \\
\text { Is the conflict in the institute used for the } \\
\text { growth of its staff? } \\
\text { Is emotion handling associated to the conflict? }\end{array}$ \\
\hline $\begin{array}{c}\text { Personality } \\
\text { variables }\end{array}$ & $\begin{array}{l}\text { In this respect this variable is not used for } \\
\text { personnel management. The } 88 \% \text { said they } \\
\text { did not know whether the variable was } \\
\text { associated with the phenomenon, the } 22 \% \\
\text { suggested it was possible to connect the } \\
\text { variable with Mobbing. }\end{array}$ & $\begin{array}{l}\text { Do the IPN officials have a psychological } \\
\text { profile? } \\
\text { Is the psychological profile used as a tool to } \\
\text { locate the person in an administrative position? } \\
\text { Does a person's personality may be related to } \\
\text { conflict? } \\
\text { Does the personality of the victim or the } \\
\text { harasser may cause Mobbing? } \\
\text { What types of personality have been more } \\
\text { problematic within the institute in relation } \\
\text { to the conflict? (Narcissistic, psychopathic, } \\
\text { paranoid). }\end{array}$ \\
\hline
\end{tabular}

HEI. Higher Education Institution.

IPN: Instituto Politécnico Nacional.

EI: Emotional Intelligence.

Note. The interview allowed us to collect the executives' opinion and compare their comments with the relevance of the variables, the comments were analyzed from Atlas ti.

Source: own elaboration with material from the cited authors.

With the obtained criteria, a content analysis was made from the conducted interviews, using as a tool the Atlas.ti program in order to prioritize the variables that later on were going to be submitted to the experts. Third, they were asked to rank the selected variables obtaining the following values: situational factors $45 \%$, cultural identity, and work organization factors $22 \%$, conflict factors $33 \%$ (these 
ones were formed by emotional intelligence factors- $18 \%$, and the harasser's and victim's personality factors - 5\%). Subsequently, we proceeded to form the matrix and the indicators election. Both variables and dimensions were adopted by taking into account the context where the study subject works; to this, we added the nor$\mathrm{ms}$, obligations, rights, regulations and legal aspects analysis.

\section{Conceptualization of the variables}

With the selected and hierarchical variables, and taking into account the characteristics of the chosen study subjects in reference to its context, the operationalization was made with the use of different theoretic criteria. See table 4.

Phase 4. To get the theoretical and operational definitions. See table 4 and based on this, to propose the theoretical model.

\section{Table 4}

\section{Theoretical and operational definitions}

\begin{tabular}{|c|c|c|}
\hline Variable & Theoretical definitions & Operational definitions \\
\hline $\begin{array}{l}\text { Situational } \\
\text { factors }\end{array}$ & $\begin{array}{l}\text { Leymann defines situational factors such as: "those who } \\
\text { are strongly related to many environment elements and } \\
\text { the work organization and that more frequent harassment } \\
\text { occurs in large, bureaucratic organizations." Leymann, } \\
\text { (1993). }\end{array}$ & $\begin{array}{l}\text { Situational factors are related } \\
\text { to the victim's performance } \\
\text { assessment, Performance of } \\
\text { harassment on the victim's } \\
\text { social groups in the workplace, } \\
\text { and the witnesses' feelings. }\end{array}$ \\
\hline $\begin{array}{c}\text { Cultural and } \\
\text { organizational } \\
\text { identity factors }\end{array}$ & $\begin{array}{l}\text { Goncalves (1997) defines organizational climate as } \\
\text { "a phenomenon that mediates between organizational } \\
\text { system factors and motivational tendencies that result in } \\
\text { behavior that has consequences for the organization such } \\
\text { as productivity, satisfaction, rotation, etc." } \\
\text { Liefooghe and Mackience (2005) define organizational } \\
\text { factors and say that when the organizational structure } \\
\text { is poor it appears the conflict and wrong management } \\
\text { are precursors of mobbing. In turn Vartia (2004), to } \\
\text { handle this variable, defines it as "the quality of work } \\
\text { environment is related to a healthy development of an } \\
\text { appropriate emotional climate". }\end{array}$ & $\begin{array}{l}\text { Cultural and organizational } \\
\text { identity factors are related to: } \\
\text { institution's culture, customs, } \\
\text { organizational culture and } \\
\text { emotional climate. }\end{array}$ \\
\hline
\end{tabular}




\begin{tabular}{|c|c|c|}
\hline Variable & Theoretical definitions & Operational definitions \\
\hline Conflict factors & $\begin{array}{l}\text { Davis and Newstrom (1999) define conflict as "any situation } \\
\text { in which two or more parties feel in opposition. It is an } \\
\text { interpersonal process that arises from disagreements about the } \\
\text { goals to achieve or the methods to use to meet those goals". } \\
\text { The organizational structure is defined as the different } \\
\text { ways in which work can be divided within an } \\
\text { organization to then achieve its coordination guiding it } \\
\text { to goal achievement (Mintzberg, 2006) Communication } \\
\text { is defined as the exchange of feelings, opinions, or any } \\
\text { other information by speech, writing or other signals } \\
\text { (Gonzales-Serna, 2007). An individual's personality } \\
\text { is related to traits, they represent reactive tendencies } \\
\text { that indicate the subject's behavior characteristics that } \\
\text { are relatively permanent, since the trait implicates a } \\
\text { configuration and behavior regularity over time and } \\
\text { situations (Cattell, 2001). }\end{array}$ & $\begin{array}{l}\text { Conflict factors are related to } \\
\text { organizational structure, and } \\
\text { communication and personal } \\
\text { aspects such as emotional } \\
\text { intelligence and personality. }\end{array}$ \\
\hline $\begin{array}{l}\text { Emotional } \\
\text { intelligence } \\
\text { factors }\end{array}$ & $\begin{array}{l}\text { Goleman (2006) defines it as: the "ability to discern } \\
\text { and respond appropriately to the moods, temperaments, } \\
\text { motivations and desires of others". } \\
\text { Gardner (2007) defines it as "the ability to make contact } \\
\text { with oneself's feelings discerning about them and use this } \\
\text { knowledge to guide our behavior". }\end{array}$ & $\begin{array}{l}\text { Emotional intelligence factors } \\
\text { formed by intraemotional and } \\
\text { interemotional intelligence are } \\
\text { important within individuals. }\end{array}$ \\
\hline $\begin{array}{c}\text { Harasser's } \\
\text { personal factors } \\
\text { and victim's } \\
\text { characteristics }\end{array}$ & $\begin{array}{l}\text { Hirigoyen (2002) defines paranoid personality as: } \\
\text { "highly suspicious of others and are generally unable to } \\
\text { recognize their own negative feelings towards others." } \\
\text { Psychopathic personality as: "people with a mental } \\
\text { disorder characterized by deficient control of emotions } \\
\text { and impulses, impulsivity, failure to adapt to moral or } \\
\text { social standards, to sociability and tendency to act and } \\
\text { antisocial behavior" and finally he sets narcissistic } \\
\text { personalities sets as: "People who have a sense of } \\
\text { superiority and an exaggerated belief of their own value } \\
\text { or importance. The individual with this personality can } \\
\text { be extremely sensitive to failure, defeat or criticism } \\
\text { and, when faced with a failure to prove the high opinion } \\
\text { of themselves, they can easily get angry or severely } \\
\text { depressed". }\end{array}$ & $\begin{array}{l}\text { Harasser's personal factors } \\
\text { (paranoid personality, } \\
\text { psychopathic personality, } \\
\text { narcissistic personality) and } \\
\text { negative characteristics of } \\
\text { the victim are important for } \\
\text { evaluation. }\end{array}$ \\
\hline
\end{tabular}

Source: Self elaboration with material from the cited authors.

An important point on building the model was to have performed a content analysis of the interviews since it made possible to select the variables to be used from the theoretical view and to take into account the actual characteristics that prevail in Higher Education Institutions of Instituto Politécnico Nacional. From the analysis, it is proposed an ex ante mobbing assessment model. See figure 1. 
Figure 1

Theoretical Model Mobbing proposal

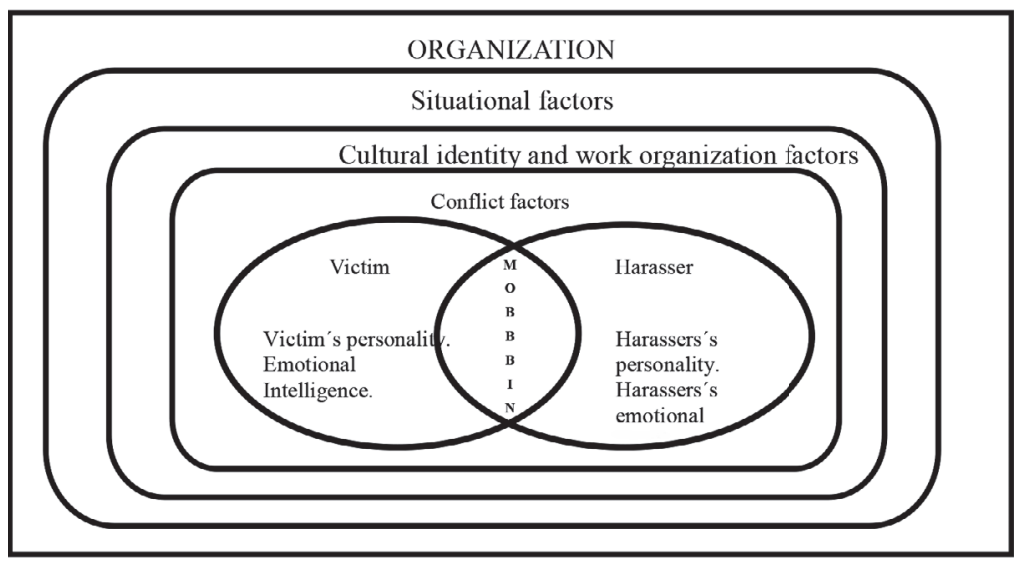

Source: own elaboration

Analysis and discussion of the theoretical model mobbing proposal

Based on the analysis performed on the variables that comprise the explanatory models about mobbing the model above is proposed (figure 1). The model goes from situational factors related to mobbing as indicated by authors like Leymann (2006), Vartia (1996, 2007), O’Moore (2003), Hubert and Veldhoven (2002), Einarsen, Raknes and Matthiesen, (1994), Zapf, Knorz and Kulla (1996). On second term, in reference to cultural identity and organizational factors, it was taken up from Cole and Grubb paper (2005) that states that poor management of cultural factors can cause conflicts. In the same way in relation to organizational structure, we used what DiMartino, Hoel and Cooper (2007), and Hirigoyen (2002) said, they mention that weak organizational structures can cause integration problems between the organizations staff. Another point immersed in the model is the organizational policy aspects mentioned by Björkqvist (1992), as some organizations have hidden policies that allow the formation of the phenomenon. In relation to conflict factors the work concepts of authors Mintzberg (2006), Gonzales-Serna (2007), Cattell (2001) were used, which allowed analyzing the psychological and personality factors. Psychological factors mentioned by Rayner and Cooper (2003) are embedded in the model. About the personality on both the victim and the aggressor, the model used the concepts of Sáez and García-Izquierdo (2001), Davenport et al., (1999). 
From the mentioned authors conceptualization and taking into account that the organization is a whole, the model presents an envelope structure where situational factors can be located anywhere within the organization for which they interact with own individuals situations concerning the culture of the place and especially concerning the institution organization (cultural identity and organizational factors). The mentioned interaction can cause conflict and bring about the mobbing phenomenon. It is important to note that when conflict shows there are specific aspects of the individual involved, namely, EI and the personality of both victims and harassers.

Mobbing is more likely present in relatively closed organizations whose internal culture considers e power and control as part of priority values on productivity and efficiency in the workplace, this being the case in most educational institutions, where groups abundant power and the institution has little to do with their performance. The two factors are risk factors that cause the phenomenon especially in vulnerable groups. Drawing on the previously established, the study was to turn women, specifically those occupying executive positions. Thus, the field of research was conducted only in women.

\section{Research scope}

The variable selection is based on different analysis. The first one carried out from studies that have helped to approach specific psychosocial problems and mobbing specifically. It also presents the key officers analysis that identifies the institution weaknesses, in addition to the Institute rules and regulation analysis. The variable selection will not only allow the mobbing quantification, but also to know how the organizational work is developing, which represents an additional point to existing models. It is also mentioned that the next step of this research is the structuring of an instrument with the selected variables which will justify the variables from empirical data and thus to propose a post facto model.

\section{Limitations of research}

Mobbing is a phenomenon that not only hurts women but also men. In this case, a variable selection limitation was performed under a gender perspective. Another weakness of the variables is that they are focused on public higher education institutions. Thus, to extrapolate the variables to other context it is needed further analysis to the study universe to be used, as well as to study subjects in order to make an adaptation of the variables chosen in this research. 


\section{Conclusions}

Mobbing is a serious health problem able to install and perpetuate aggressive behavior in organizations and companies, and affects the family and social environment of the aggressors and victims.

The state of the art review revealed the lack of an instrument which in addition to quantifying the mobbing allows to inform about weak points of the organization in relation to the emotional intelligence and personality of the victims and harassers.

On mobbing studies about personality there are some studies that characterize harassers, but nothing about the victim. There is little research in specific productive sectors. Neither there are research relating Mobbing and intelligence. The explanatory variables of mobbing have little uniformity. There are no studies on the economic impact that the phenomenon causes.

The main finding is that there is a lack of an explanatory model of mobbing in women in a higher education institution. Therefore, the proposed model is a contribution to the scientific study of human behavior in the context of administration, made from the perspective of gender. The gender perspective is taken as key to the interpretation of society that seeks to discern and denounce the cultural conditions that oppress women and in turn, promotes efforts to liberate women from these constraints. The conviction of the authors of this paper is that we must contribute to the knowledge of mobbing, identify and quantify the incidence, causes and effects, to perform empirical studies, to disseminate results and to raise awareness in the population.

In Mexico, there is no specific labor legislation on Mobbing. A law on non-violence in women has just been released, but its emphasis is focused on criminal and family violence and it is not workplace oriented. Work on mobbing is needed in specific sectors.

It is worth noting that a difficult aspect to achieve model building is attached to the characteristics of the universe and study subjects used, as in the case of this research, the authors believe that this study is only the tip of the iceberg, and gets a quantitative model to allow the construction of a specific instrument, which allows to perform quantifications in various sectors to achieve standardization of the instrument, and observe what the variables are that must form the model. 


\section{References}

Adams, W. and M. Crawford (1992). Workplace aggression. In A. Sagie, M. Koslowsky y S. Stashervsky (eds.). Misbehavior and Dysfunctional Attitudes in Organizations. New York: Palgrave Macmillan.

Alburqueque, J. (2006). Amos Version 4.01, Analysis of moment structures. Chicago: Small Waters Corporation.

Agervold, J. (2002). Emotional Abuse in the Workplace: Conceptual and Empirical Issues. Journal of Emotional Abuse 6 (1): 85-117.

Ashforth, B. (1994). Petty tyranny in organizations. Human Relations 47 (7): 755-778.

Barbieri, T. de (2005). Sobre la categoría de género. Una introducción teórica metodológica. ISIS Internacional (17).

Barón, R. and J. Neuman (1998). Agresión de lugar de trabajo. El iceberg bajo la punta de violencia de lugar de trabajo: Evidencia de sus formas, frecuencia, y objetivos. Administración Pública 21 (4): 446-464.

Barón Duque, M. (2003). La espiral del mobbing. Valencia: Fundación de la Comunidad Valenciana para la Prevención de Riesgos Laborales.

Baumeister, R., T. Heatherton and D. Tice (1993). When ego threats lead to self-regulation failure: Negative consequences of high self-esteem. Journal of Personality and Social Psychology (64): 141-156.

Benhabib, S. and D. Cornel (2002). Teoría feminista y teoría crítica. Valencia: Alfons el Magnánim, 9-28.

Björkqvist, K. (1992). Trakassering förekommer bland anstaällda vid. A.A. Meddelanden fran Abo Akademi (9):14-17.

,F. Cols and M. Vartia (2002). Aggression among university employees. Aggressive Behavior (20): 173-184. 
, K. Österman and K. Lagerspetz, K. (2005). Sex differences in covert aggression among adults. Aggressive Behavior (20): 27-33.

Brodsky, C. (1976). The harassed worker. Toronto: Lexington Books, DC Heath and Company.

Cattell, R. (2001). Teoría analítica factorial. Madrid: Buena Imagen.

Cole, L. and P. Grubb (2005). Psychological correlates of harassment, threats and fear of violence in the workplace. Scandinavian Journal of Work, Environment and Health 23 (6).

Cortés, V. (2009). Conociendo el Mobbing. Voz laboral 5.

Davenport, N., D. Schwatrz, R. Pursell and G. Elliott (1999). Mobbing: emotional abuse in the American workplace. Iowa: Civil Society Publishing.

Daza, M. (2007) El estrés: proceso de generación en el ámbito laboral. Disponible en: http://www.mtas.es/insht/ntp/ntp_318.htm.

(2008). Medidas preventivas en formación profesional sobre estrés laboral. Disponible en http://www.mtas.es/insh3/notaspracticas.htm.

Davis K. and J. Newstrom (1999). Comportamiento humano en el trabajo, 10a. ed. México: McGraw-Hill.

Di Martino, V., H. Hoel, and C. Cooper (2003). Psychosocial risk factors and work-related bullying: interventions. European Week for Safety and Health at Work, 2002, European Agency for Safety and health at Work, Bilbao.

, H. Hoel and C. Cooper (2007). Preventing violence and harassment in the workplace. Dublín. European Foundation for the improvement of living and working conditions.

Dormann, C. and D. Zapf (2002). Social stressors at work, irritation, and depressive symptoms: Accounting for unmeasured third variables in a multi-wave study. Journal of Occupational and Organizational Psychology 75 (1): 33-58. 
Einarsen, S. (2000). Harassment and bullying at work: a review of the Scandinavian approach. Aggress Violent Behave 4 (5): 405-401.

B. Raknes and S. Matthiesen (1994). Bullying and harassment at work and their relations to work environment quality. An exploratory study. The European Work and Organizational Psychology (4): 381-401.

and A. Skogstad (1996). Bullying at work: epidemiological findings in public and private organizations. European Journal of Work and Organizational Psychology (5): 185-201.

, B. Raknes and S. Matthiesen (1997). Harassment at work and victimization of men. Violence and Victims (12): 247-263.

and H. Hoel (2001). The Negative Acts Questionnaire: development, validation and revision of a measure of bullying at work. Paper presented, and the $10^{\mathrm{a}}$ European Congress on Work and Organizational Psychology. Praga.

, H. Hoel, D. Zapf and C. Cooper (2003a). The concept of bullying at work. En S. Einarsen, H. Hoel, D. Zapf and C. Cooper (eds.). Bullying and Emotional Abuse in the Workplace. International perspectives in research and practice. London: Taylor y Francis Books Ltd, 3-30.

and E. Mikkelsen (2003b). Individual effects of exposure to bullying at work. En S. Einarsen, H. Hoel, D. Zapf and C. Cooper (eds.). Bullying and emotional abuse in the workplace. International perspectives in research and practice. London: Taylor and Francis Books Ltd.

and L. Hauge (2006). Antecedentes y consecuencias del acoso psicológico en el trabajo: una revisión de la literatura. Revista de Psicología del Trabajo y de las Organizaciones 22 (3): 251-274.

Elovainio, M., M. Kivimaki and J. Vahtera (2002). Organizational justice: Evidence of a new psychosocial predictor of health. American Journal of Public Health 92 (1): 105-108.

Ferrie, L., I. Shipley, R. Marmot, D. Stansfeld and F. Smith (1998). The dispositional approach to job attitudes. A lifetime longitudinal test. Administrative Science Quarterly 31 (1): 59-78. 
Fisher, R., W. Ury and B. Patton (1992). Obtenga el sí o el arte de negociar sin ceder. Barcelona: Gestión 2000.

Fondevila, C. (2008). Social undermining in the workplace. Academy of Management Journal 2 (45): 331-35.

Galtung, J. (1998). Abuse at work drains people, money, and medical workplace not immune. Journal of American Medical Association (267): 1439-1440.

García-Izquierdo, M., B. Llor, M. Sáez, J. Ruiz, J. Blasco and M. Campillo (2004). Evaluación del acoso psicológico en el trabajo: El NAQ-RE. Revisión de la adaptación española. Comunicación oral presentada en el el VII European Conference On Psychological Assessment, Málaga, España.

and M. Sáez (2007). Los factores Psicosociales de riesgo en el trabajo como predictores del mobbing. Psicothema 19 (002): 225-230.

Gardner, H. (2007). Truth, Beauty, and Goodness Reframed: Educating for the Virtues in the Twenty-First Century. New York: Basic Books.

Gil, A., (2002). Mobbing o acoso moral en el trabajo. Economist and Jurist 10 (56): 12 .

Goldberg, D. (1972). Employee accounts of bullying at work. International and Decision Making 4 (1): 24-34.

Goleman, D. (2006), La práctica de la inteligencia emocional. Barcelona: Kairós.

Goncalves, A. (1997). Dimensiones del clima organizacional. Disponible en: http://www.ilustrados.com/tema/2084/Diagnostico-satisfaccion-laboralempresa-textil-peruana.html.

Gonzales- Serna, S. (2007). Lenguaje y comunicación. IES: Carmen la Font (San José de la Rinconada Sevilla).

González de Rivera, J. (2005). El mobbing en las organizaciones. Barcelona: Kairos. 
and M. Rodríguez-Abuín (2006). Acoso psicológico en el trabajo y psicopatología: un estudio con el LIPT-60 y el SCL-90-R. Revista de Psicología del Trabajo y de las Organizaciones 22 (3): 397-412.

Hirigoyen, M. (1999). El acoso moral en el trabajo y la personalidad del acosador. Valencia: Fundación de la Comunidad Valenciana para la Prevención de Riesgos Laborales.

(2002a). El acoso moral. Barcelona: Paidós.

(2002b). Le harcèlement moral dans la vie professionnelle. Paris: Éditions la Découverte et Syros.

(2002c). Mobbing: definición y límites. En respuestas al Mobbing en el ámbito laboral. Victoria-Gasteiz: Gobierno Vasco 93.

(2004). El acoso moral en el trabajo. Barcelona: Paidós.

(2006). Mujeres maltratadas: los mecanismos de la violencia en la pareja. Barcelona: Paidós.

Hoel, H., D. Zapf and C. Cooper (2003). Destructive conflict and bullying at work. Unpublished report. University of Manchester.

Hubert, J. and O. Veldhoven (2002). The health and safety of men and women at work. Eurostat Statistics In Focus, Theme 3 (4): 56-75.

Jares, X. (1999). Educación y derechos humanos. Estrategias didácticas y organizativas. Madrid: Popular (también en edición en gallego de 1998, Vigo: Edicións Xerais)

(2001). Aprender a convivir. Vigo: Xerais

Juárez, C. (2005). Mobbing un riesgo psicosocial latente en el trabajo de enfermería. Disponible en http://www.imss.gob.mx/NR/rdonlyres/ 5D2F5911-0D8A-4125A5C6051E3FB0655A/0/vol13_3mobbing.pdf. 
Kahlor, M. and J. Amin. (2006). El impacto de acoso en las mujeres dentro de su trabajo: la autoestima como factor de re silencia en el afrontamiento y la respuesta. The sciense and ingeenering 61 (5B).

Knorz, C. and D. Zapt (2003). Workplace Mobbing. En C.L. Cooper and I.T. Robertson (eds.). International Review of Industrial and Organizational Psychology (14): 195-230. Chichester: Wiley.

Langner, T. (1996). The affective revolution in organizational behavior: The emergence of paradigm. En J. Greenberg, Ed. Organizational Behavior: The state of the science. Lenders: Ed. Lawrense Science/JAI Press, 3-52.

Langner, T. (1962). Classificazione delle sindromi e dei disturbi psichici e comportamentali. World Health Organization, Masson.

Lederach, J. (1984). The regulation of social conflict. A practical approach. Akron, PA: Mennonite Central Committee.

tarata.

(1994). El ABC de la paz y los conflictos. Madrid: Los libros de la ca-

(1996). ¿Conflicto y violencia? ¡Busquemos alternativas creativas! Guía para facilitadores. Guatemala: Ediciones Clara-Semilla.

Leymann, H. (1984). Vuxenmobbning: om psykiskt våld $i$ arbetslivet. Lund: Studentlitteratur.

(1987). Mobbing and psychological terror at workplaces. Violence and Victims (5): 119-126.

(1990). Employee accounts of bullying at work. International and Decision Makin 4 (1): 24-34.

(1993). Investigation into the frequency of adult mobbing in a Swedish steel company using LIPT. Questionnaire (unpublished manuscript) 67.

(1996a). Mobbing, Psychoterror am Arbeitsplatz und wie man sichdagegen wehren kann. Reinbeck bei Hamburg: Rowohlt. 
(1996b). The content and development of bullying at work. European Journal of Work and Organizational Psychology (5): 165-184.

(1997). The mobbing encyclopedia. Bullying. The definition of mobbing at workplaces. Paris: Du Seuil.

(2006). The content and development of mobbing at work. European Journal of Work and Organizational Psychology 5 (2): 165-184.

and A. Gustafsson (1996). Mobbing at work and the development of post-traumatic stress disorder. European Journal of Work and Organizational Psychology, 5 (2): 251-275.

Liefooghe, A. and D. McKenzie (2005). Explaining bullying at work: Why should we listen to employee accounts? En S. Einarsen, H., Hoel, D. Zapf and C. Cooper (eds.) Bullying and Emotional Abuse in the Workplace. International perspectives in research and practice. London: Taylor y Francis Books Ltd, 219-230.

Lindroth, J. and H. Leymann (2001). Accounts of workplace bullying: The role of the organization. European Journal of Work and Organizational Psychology 10 (4): 375-392.

López, J., H. Hoel and D. Zapf (1994). Mobbing en puestos de trabajo de tipo administrativo. Medicina Del Trabajo 5 (6): 19-28.

MacDonald, L., R. Karasek, L. Punnett and T. Scharf (2001). Covariation between workplace physical and psychosocial stressors: Evidence and implications for occupational health research and prevention. Ergonomics 44 (7): 696-718.

Matthiesen, S. and L. Cols (2001a). Harassment and bullying at work: A review of the Scandinavian approach. Aggression and Violent Behaviour 5 (4): 379-401.

and S. Einarsen (2001b). MMPI-2 configurations among victims of bullying at work. European Journal of Work and Organizational Psychology 10 (4): 467-484. 
and S. Einarsen (2004). Psychiatric distress and symptoms of PTSD among victims of bullying at work. British Journal of Guidance and Counselling 32 (3): 335-356.

Matud, M., A. Carballeira, Q. Marrero, Á. Aguilera, P. Moraza and T. Pérez (2006). Características sociodemográficas y conductuales de los agresores a su pareja: un análisis a través del informe de las víctimas. Psicopatología clínica, legal y forense 2 (2): 5- 22.

Medina, F., M. Dorado, L. Munduate, A. Arévalo and I. Cisneros (2002). Secuencias conductuales en la efectividad de la gestión del conflicto. Psicothema 14.

Mikkelsen, E. and S. Einarsen (2002a). Basic assumptions and symptoms of post-traumatic stress among victims of bullying at work. European Journal of Work and Organizational Psychology 11 (1): 87-111.

and S. Einarsen (2002b). Relationships between exposure to bullying at work and psychological and psychosomatic health complains: The role of state negative affectivity and generalized self-efficacy. Scandinavian Journal of Psychology (43): 397-405.

Ministry of Labour and Social Affairs, (2007) Ordenanza sobre el acoso en el lugar de trabajo. Estocolmo: Agencia Sueca para el Entorno Laboral.

Mintzberg, H. (2006). Diseño de Organizaciones Eficientes. Panavox computer systems.

Morán-Astorga, C. (2002). The relevance of organizational factors on the occurrence of mobbing. Psychology \& Health 19.

Moreno-Jiménez, B., M. Rodríguez, M. Morante and R. Rodríguez (2004). The relevance of organizational factors on the occurrence of mobbing. Psycho Health (19): 118.

, A. Rodríguez-Muñoz, E. Garrosa and M. Morante (2005). Antecedentes organizacionales del acoso psicológico en el trabajo: un estudio exploratorio. Psicothema 17 (4): 627-632. 
O'Moore, M. (2003). Bullying at Working Ireland: A National Study. Dublin: Anti-Bullying Centre.

Pando, M., J. Ocampo de Águila, M. Águila, T. Castañeda and S. Amezcua (2009). Factores psicosociales y presencia de mobbing en profesores universitarios. Revista de salud Pública y nutrición 9 (3).

Peña, S., B. Ravelo and D. Sánchez (2007). Cuando el trabajo nos castiga. Debates sobre el mobbing. México: Ediciones Eón y UAM Azcapotzalco.

PND (2007-2012). Los objetivos generales del Plan Nacional de desarrollo. México: Poder Legislativo.

Pérez-Bilbao, J., C. Nogareda, F. Martín-Daza and T. Sancho (2001). Mobbing, violencia física y acoso sexual. Madrid: Instituto Nacional de Seguridad e Higiene en el Trabajo.

Piñuel y Zavala, I. (2001). Estudio Barómetro Cisneros II. Madrid: Universidad de Alcalá de Henares.

(2007). Estudio Barómetro Cisneros VIII. Madrid: Universidad de Alcalá de Henares.

Quine, L. (1996). Informe UMTI, referente a la salud de los trabajadores ingleses. Luxemburg: Office for the Official Publicationes.

(2000). Workplace bulling in NHS community trust: staff questionnaire survey. British Medical Journal (318): 228-232.

Rodríguez, M. (2007). Inteligencia emocional en situaciones de estrés laboral. España: Amares.

Rayner, C. and C. Cooper (2003). The black hole in mobbing at work research. Int. J. Management and Decision Making 4 (1): 47-64. 
Rosas, S. (2008). Mobbing factor de riesgo y de seguridad estudio comparativo con sindrome burnout en profesionales de salud del Hospital General de Pachuca, Hidalgo, México. Revista Cientifica Electronica de Psicología ICSa-UAEH (6), [Versión electrónica]. Disponible en http://dgsa.uaeh.edu.

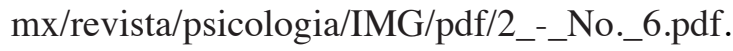

Sáez, M. and M. García-Izquierdo (2001). Violencia psicológica en el trabajo: el mobbing. En J. Buendía y F. Ramos (eds.). Empleo, estrés y salud. Madrid: Pirámide, 191-205.

Scott, J. (2003). El género: una categoría útil para el análisis histórico. In J. Amelang y Mary Nash, comps. Historia y género: las mujeres en la Europa moderna y contemporánea. Barcelona: Alfons el Magnanim.

Skogstad, A. (1996). Bullying at work. Epidemiological findings in public and private organizations. European Journal of Work and Organizational Psychology 5: 185-203.

Thylefors, I. (1987). Syndabockar - Om utstötning och Mobbing $i$ arbetslivet. Stockholm: Natur och Kultur.

Van Dick, L. and M. Wagner (2004). Abuse at work drains people, money and medical work-place not immune. Journal of American Medical Association (267): 1439-1440.

Vartia, M. (1996a). Mobbing and wellbeing: economic and personal development implications. European Journal of Work and Organizational Psychology (5): 139-150.

(1996b). The sources go bullying-psychological work environment and organizational climate. European Journal of Work and Organizational Psychology (5): 203-215.

(2004). Workplace Mobbing: The role of occupational health services, and emotional abuse in the work place. In S. Einarsen et al. (eds.). International perspectives in research and practice. London/New York: Taylor and Francis. 
(2006). Psychological harassment (bullying, mobbing) at work. OECD Panel on women, work, and health, Ministry of Social Affairs and Health, Helsinki.

(2007). Consequences of workplace bullying with respect to the well-being of its targets and the observers of bullying. Scandinavian Journal of Work 27 (1): 63-69.

Zapf, D., C. Knorz y M. Kulla (1996). On the relationship between mobbing factors, and job content, social work environment, and health outcomes european. Journal of Work and Organizational Psychology 5 (2): 399-412.

and M. Cross (2001a). Organizational, work group related and personal causes of mobbing/bullying at work. International Journal of Manpower 20 (12): 70-82.

and C. Gross (2001). Conflict escalation and coping with workplace bullying: A replication and extension. European Journal of Work and Organizational Psychology (10): 497-522.

and S. Einarsen (2003). Individual antecedents of bullying: victims and perpetrators. In S. Einarsen, H. Hoel, D. Zapf y C. Cooper (eds.). Bullying and Emotional Abuse in the Workplace: International Perspectives in Research and Practice. London: Taylor y Francis Books Ltd, 165-184. 